\title{
Ruminal availability of nitrogen and carbohydrates from fresh and preserved herbage in dairy cows
}

\author{
A. M. VAN VUUREN ${ }^{1}$, S. TAMMINGA ${ }^{2} \&$ R. S. KETELAAR ${ }^{3}$ \\ 1 Research Institute for Livestock Feeding and Nutrition, P.O. Box 160, NL 8200 AD \\ Lelystad, Netherlands \\ 2 Present address: Department of Animal Nutrition, Wageningen Agricultural University, \\ Haagsteeg 4, NL 6708 PM Wageningen, Netherlands \\ ${ }^{3}$ Present address: Experimental Farm 'Groot Kantwijk', UT Delfia BV, Bergseweg 28, \\ NL 3633 AK Vreelant, Netherlands
}

Received 16 March 1990; accepted 11 April 1990

\begin{abstract}
Ruminal degradabilities of crude protein and non-protein organic matter of fresh and preserved herbage, obtained with nylon bag studies, were compared and consequences for dairy cow rations were discussed. In Experiment 1 the effect of rate of fertilization on the in sacco degradation of fresh grass was studied. The second experiment focussed on the effect of maturation on fresh grass. In Experiments 3 and 4 the influence of maturation and dry matter content on the in sacco degradation of grass silage and hay was studied. Experiment 4 also included treatment with cell wall degrading enzymes. Fresh and preserved herbage fertilized at high rates of nitrogen, had a large surplus of fermentable nitrogen. In fresh herbage the ratio of soluble nitrogen:soluble non-protein organic matter ('carbohydrates') was lower than the ratio of insoluble, degraded nitrogen:insoluble, degraded carbohydrates. Therefore it was concluded that ingredients with a low ratio of insoluble, degraded nitrogen:insoluble, degraded carbohydrates may be appropiate supplements for grass-based diets. In preserved herbage the ratio of soluble nitrogen:soluble carbohydrates exceeded the ratio of insoluble, degraded nitrogen:insoluble, degraded carbohydrates. Wilting had no consistent effect on the ratios of nitrogen:carbohydrates. Treatment with cell wall degrading enzymes resulted in a lower ratio of soluble nitrogen:soluble carbohydrates. It was suggested that silage-based diets require supplementation with ingredients rich in soluble carbohydrates.
\end{abstract}

Keywords: rumen availability, in sacco degradation, nitrogen, carbohydrates

\section{Introduction}

Herbage, either fresh or preserved (hay, silage) features largely in the nutrient supply of ruminants. In the Netherlands, grass and grass products make up 50 to $60 \%$ of the total energy intake of a dairy cow. The chemical composition of grass and grass products may vary considerably and depends on a wide range of genetic and environmental factors (Gill et al., 1989) such as grass species and variety, rate of fertilization, solar radiation, rainfall, maturity at time of grazing or harvesting and 
method of preservation (Henderson et al., 1982). These factors not only influence composition but also the rate and extent of ruminal and intestinal degradation (Tamminga et al., 1990a; van Vuuren et al., 1989) and as a result the intake of the various components.

Highly fertilized, young herbage is characterized by a high content of crude protein (CP) and a high rate and extent of degradation of CP, causing high concentrations of ammonia- $\mathrm{N}$ in the rumen (van Vuuren et al., 1986) and substantial $\mathrm{N}$ losses via urinary excretion. In grass silages a variable proportion of $\mathrm{CP}$ will become solubilized and consequently becomes even more rapidly degradable in the rumen and poorly utilizable by micro-organisms (Thomas, 1982).

A better utilization of nutrients, especially $\mathrm{N}$, seems possible by matching the supply of rumen-degradable $\mathrm{N}$ and carbohydrates. Czerkawski (1986) calculated from stoichiometric considerations an equilibrium with a capture of 22.7 to $27.7 \mathrm{~g} \mathrm{~N}$ per $\mathrm{kg}$ OM fermented, while in vivo determinations produced an average efficiency of $19.3 \mathrm{~g} \mathrm{~N}$ per $\mathrm{kg}$ OM fermented. Thus from a $\mathrm{N}$ economy the optimal ratio of $\mathrm{N}$ to $\mathrm{OM}$ fermented is around $25 \mathrm{~g} \mathrm{~kg}^{-1}$. Under conditions of an optimal $\mathrm{N}$ economy, synchronization of available energy and $\mathrm{N}$ to the rumen biota is likely to be another important condition for an improved utilization of $\mathrm{N}$.

Rumen micro-organisms use carbohydrates as their main energy source. In fresh herbage soluble sugars, fructosans and cell wall polysaccharides are the main carbohydrates. In silages the sugars and fructosans are pre-fermented to a variable degree. In fresh forages 70 to $90 \%$ of $\mathrm{N}$ is present in true protein (Tamminga, 1986), mainly in soluble enzymes in chloroplasts and cytoplasm and in insoluble proteins (mainly chlorophyll) in the chloroplast membrane (Mangan, 1982). Sugars, fructosans and soluble $\mathrm{N}$ components are supposed to be instantly available for the rumen biota and therefore assumed to possess an infinite rate of degradation. Cell wall components and insoluble $\mathrm{N}$ components are however degraded at much slower but variable rates.

The objective of this study was to obtain information on the ratio of $\mathrm{N}$ and carbohydrates in rumen soluble, rumen insoluble effectively fermented, potentially degradable but escaping rumen fermentation and undegradable components in grass and grass silages from estimates of the disappearance of nutrients from nylon bags suspended in the rumen (Mehrez \& Orskov, 1977). Such information is required in order to understand how to optimize grass or silage-based rations.

\section{Material and methods}

\section{Forages}

In Experiments 1 and 2 the degradation of rye grass (Lolium perenne) was studied with nylon bag incubations in the rumen of cows. In Experiments 3 and 4 the degradation of grass silages was investigated with the same technique.

In Experiment 1, herbage originated from 8 different plots cut weekly. Mowing height was approximately $4 \mathrm{~cm}$. Four plots were laid out on sandy soil, the others on clay soil. On each type of soil 4 rates of nitrogen fertilization were applied, result- 
ing in $0,250,400$ and $700 \mathrm{~kg} \mathrm{~N} \mathrm{ha}^{-1} \mathrm{yr}^{-1}$, respectively. The herbage cut on May 14 (sandy) and 21 (clay), July 8 (sandy) and 15 (clay) and September 12 (sandy) and 19 (clay) 1985 was sampled and taken to the laboratory in cooling boxes. The herbage was chopped with a paper guillotine to a particle length of approximately 1 $\mathrm{cm}$. Nylon bags (polyamide $190 \times 100 \mathrm{~mm}$, mesh size $41 \mu \mathrm{m}$, porosity $30 \%$; Nybolt, Switzerland) were filled with approximately $30 \mathrm{~g}$ of fresh material, equivalent to $5 \mathrm{~g}$ dry matter (DM). Bags were tied and stored at $-18^{\circ} \mathrm{C}$ until rumen incubations. Sample preparations were carried out in a climatic room at $4-7^{\circ} \mathrm{C}$. A 600 $\mathrm{g}$ sample was lyophilized, ground to pass a $1 \mathrm{~mm}$ screen and stored for proximate and cell wall analyses.

Experiment 2 focussed on the effect of maturity on CP content and ruminal disappearance. In June and July 1985, herbage was sampled every seventh day, starting 9 days after previous cutting. For 8 consecutive weeks strips of one plot were mowed with a cutter bar at a height of approximately $4 \mathrm{~cm}$. Samples and nylon bags were prepared as in Experiment 1.

In Experiment 3, herbage samples of week 2, 4, 6 and 8 of Experiment 2 were chopped and ensiled in 1.51 preservation jars either directly or after wilting in the laboratory to reach DM levels of ca 300 and $450 \mathrm{~g} \mathrm{~kg}^{-1}$. After 90 days, jars were opened and nylon bags were filled with the silage (approximately $5 \mathrm{~g} \mathrm{DM}$ ) and stored at $-18^{\circ} \mathrm{C}$ until rumen incubation. Another proportion of the sample was dried to reach a $\mathrm{DM}$ content of ca $875 \mathrm{~g} \mathrm{~kg}^{-1}$ (hay) and put into nylon bags. Samples of silages and hay were oven-dried at $70^{\circ} \mathrm{C}$, ground to pass a $1 \mathrm{~mm}$ screen and stored for proximate and cell wall analyses.

In Experiment 4, herbage was harvested from one plot 2, 4 and 6 weeks after the previous cut and ensiled either directly or after wilting to a DM content of 300 and $450 \mathrm{~g} \mathrm{~kg}^{-1}$ and with or without the addition of cell wall degrading enzymes. Detailed information on experiment 4 has been published elsewhere (van Vuuren et al., 1989).

\section{Nylon bag incubations and analyses}

Dried samples of the original material were analysed for DM, N and neutral detergent fibre (NDF) as described previously (van Vuuren et al., 1989).

Nylon bags incubations were carried out as described by van Vuuren et al. (1989) in the rumen of three dairy cows, surgically prepared with a large rumen cannula (Bar Diamond, Idaho, USA). Incubation times were 0, 3, 6, 12, 24 and $48 \mathrm{~h}$ and 9 (Experiments 1 and 2) or 14 (Experiments 3 and 4) days. After removal from the rumen, bags were rinsed with water and subsequently washed in a domestic washing machine, without spinning. The bags were dried at $70^{\circ} \mathrm{C}$ and weighed. The residues were ground to pass a $1 \mathrm{~mm}$ screen and analysed for DM, ash and $\mathrm{N}$, the former to be used to correct the $\mathrm{N}$ and ash values. Analyses were carried out as described previously (van Vuuren et al., 1989).

The instantly degradable, soluble fraction (S) was estimated as the fraction disappearing from the bags during washing (zero incubation time). The residues present in the nylon bags after the various times of incubation were fitted using a first-order 
model, including an insoluble, potentially degradable fraction (D), degraded at constant rate $\left(\mathrm{k}_{\mathrm{d}}\right)$, and an undegradable fraction $(\mathrm{U})$. The undegradable fraction was measured as the residue after long-term incubation: 9 or 14 days (Robinson et al., 1986).

The primary aim of these studies was to estimate the proportion of $\mathrm{CP}$ assumed to be fermented in the rumen. Thus, only limited numbers of bags were incubated and consequently only small quantities of feed residues per incubation time were recovered, especially from the bags incubated 9 or 14 days. After ash and $\mathrm{N}$ analyses the quantity of feed residues was insufficient for the determination of cell wall carbohydrates. Therefore the disappearance of non-protein, non-fat organic matter was used as an estimate of carbohydrate (CB) degradation. The OM in the silages was not corrected for volatile components.

The contents of fermented $\mathrm{N}(\mathrm{FN})$ and fermented $\mathrm{CB}$ (FCB) per kg DM were estimated according to the formula:

$$
\text { FN or } \mathrm{FCB}=\left[\frac{\mathrm{k}_{\mathrm{d}}}{\mathrm{k}_{\mathrm{d}}+\mathrm{k}_{\mathrm{p}}} \times \mathrm{D}+\mathrm{S}\right] \times \mathrm{N} \text { or } \mathrm{CB}
$$

where:

$\mathrm{k}_{\mathrm{d}}=$ rate of degradation of $\mathrm{N}$ or $\mathrm{CB}\left(\mathrm{h}^{-1}\right)$

$\mathrm{k}_{\mathrm{p}}=$ rate of passage, assumed $0.045 \mathrm{~h}^{-1}$

$\mathrm{D}=$ insoluble, potentially degradable fraction of $\mathrm{N}$ or $\mathrm{CB}$

$\mathrm{S}=$ instantly degradable fraction of $\mathrm{N}$ or $\mathrm{CB}$

The content of soluble, instantly degradable $N(S N)$ was calculated as $\left[S_{n} \times N\right]$; soluble carbohydrate $(\mathrm{SCB})$ as $\left[\mathrm{S}_{\mathrm{om}} \times \mathrm{OM}-\mathrm{S}_{\mathrm{cp}} \times \mathrm{CP}\right]$. The contents of insoluble $\mathrm{N}(\mathrm{EN})$ and $\mathrm{CB}(\mathrm{ECB})$ assumed to be fermented in the rumen were estimated as $[\mathrm{FN}-\mathrm{SN}]$ and $[\mathrm{FCB}-\mathrm{SCB}]$, respectively. Undegradable $\mathrm{N}(\mathrm{UN})$ was calculated as $\left[\mathrm{U}_{\mathrm{n}} \times \mathrm{N}\right]$ and undegradable $\mathrm{CB}(\mathrm{UCB})$ as $\left[\mathrm{U}_{\mathrm{cb}} \times \mathrm{CB}\right]$.

We also estimated the contents of potentially degradable $\mathrm{N}$ and $\mathrm{CB}$ escaping from rumen fermentation according to the formula:

$$
\text { PDN or PDCB }=\left[\frac{k_{p}}{k_{d}+k_{p}} \times D\right] \times N \text { or } C B
$$

where:

$\mathrm{k}_{\mathrm{p}}=$ rate of passage, assumed $0.045 \mathrm{~h}^{-1}$

$\mathrm{k}_{\mathrm{d}}=$ rate of degradation of $\mathrm{N}$ or $\mathrm{CB}\left(\mathrm{h}^{-1}\right)$

$\mathrm{D}=$ insoluble, potentially degradable fraction of $\mathrm{N}$ or $\mathrm{CB}$

Relationships between chemical composition and rumen availability were quantified using multiple regression analysis (Payne et al. 1987). Effects of treatments were subjected to analysis of variance. 


\section{Results}

\section{Effect of rate of $N$ fertilization (Experiment 1)}

In Experiment 1 the $\mathrm{N}$ content of herbage ranged between 27.3 and $60.7 \mathrm{~g} \mathrm{~kg}^{-1}$ $\mathrm{DM}$ and increased with increasing rate of $\mathrm{N}$ fertilization. At the higher $\mathrm{N}$ rates the proportion of UN was lower and that of $\mathrm{FN}$ higher than at low $\mathrm{N}$ rates. The effect of rate of $\mathrm{N}$ fertilization on the soluble and insoluble rumen-degradable fractions varied and depended on the time between $\mathrm{N}$ fertilization of the plots and sampling of the grass (van Vuuren, unpublished). Since effects of type of soil were not apparent, results from both types of soil were pooled per $\mathrm{N}$ rate.

The $\mathrm{CB}$ content of herbage decreased with increasing $\mathrm{N}$ fertilization (Figure 1). This decrease was mainly a decrease of PDCB. The proportion of FCB was higher at higher $\mathrm{N}$ rates. The content of UCB increased with the season.

The FN:FCB ratio ranged between 46.2 and $159.9 \mathrm{~g} \mathrm{~N} \mathrm{~kg}^{-1} \mathrm{CB}$ and was strongly correlated with the $\mathrm{N}$ content $(\mathrm{R}=0.98)$. Figure 2 shows that the $\mathrm{SN}: \mathrm{SCB}$ ratio was lower than the EN:ECB ratio, except in May at the highest $\mathrm{N}$ rate, when $\mathrm{SN}: \mathrm{SCB}$ exceeded the $\mathrm{EN}: \mathrm{ECB}$ ratio. Also in May, the SN:SCB ratio at $0 \mathrm{~kg} \mathrm{~N}$ $\mathrm{ha}^{-1}$ was lower than $25 \mathrm{~g} \mathrm{~kg}^{-1}$, the ratio at which microbial growth is assumed to be optimum (Czerkawski, 1986). The EN:ECB ratios were always higher than $25 \mathrm{~g}$ $\mathrm{kg}^{-1}$.

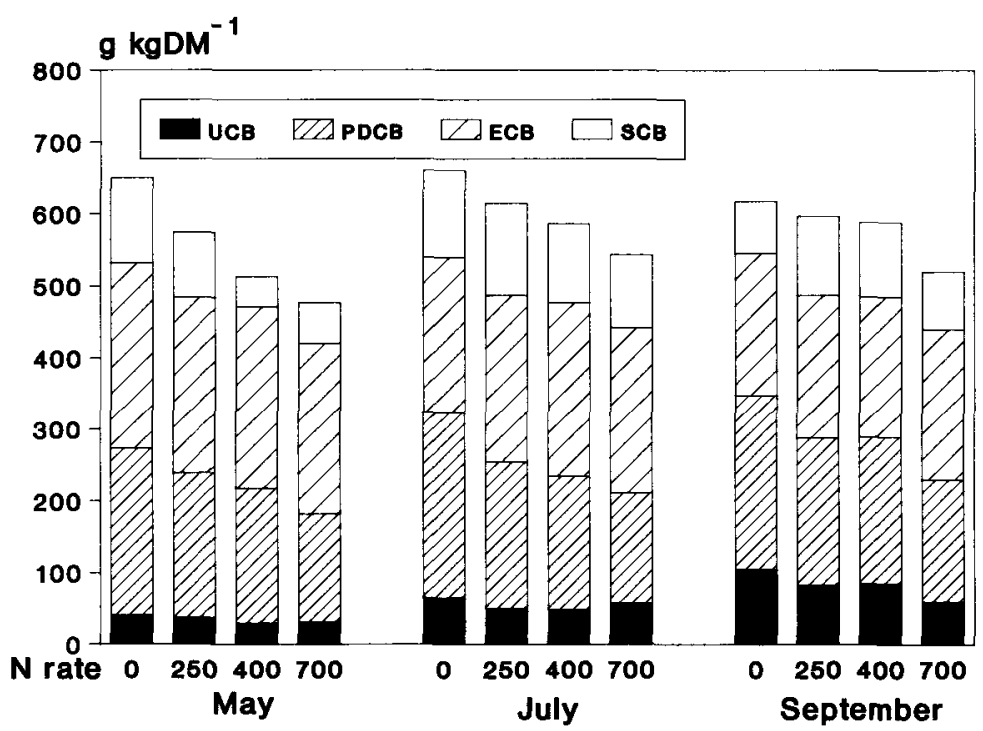

Fig. 1. Effect of rate of nitrogen fertilization $\left(0,250,400\right.$ and $700 \mathrm{~kg} \mathrm{ha}^{-1} \mathrm{yr}^{-1}$, respectively) and season on carbohydrate (CB) in fresh herbage (Lolium perenne). Experiment 1. (UCB = undegradable $\mathrm{CB}$; $\mathrm{PDCB}=$ potentially degradable $\mathrm{CB}$ escaping from rumen fermentation; $\mathrm{ECB}=$ potentially degradable $\mathrm{CB}$ effectively fermended in the rumen; $\mathrm{SCB}=$ soluble $\mathrm{CB}$ ). 

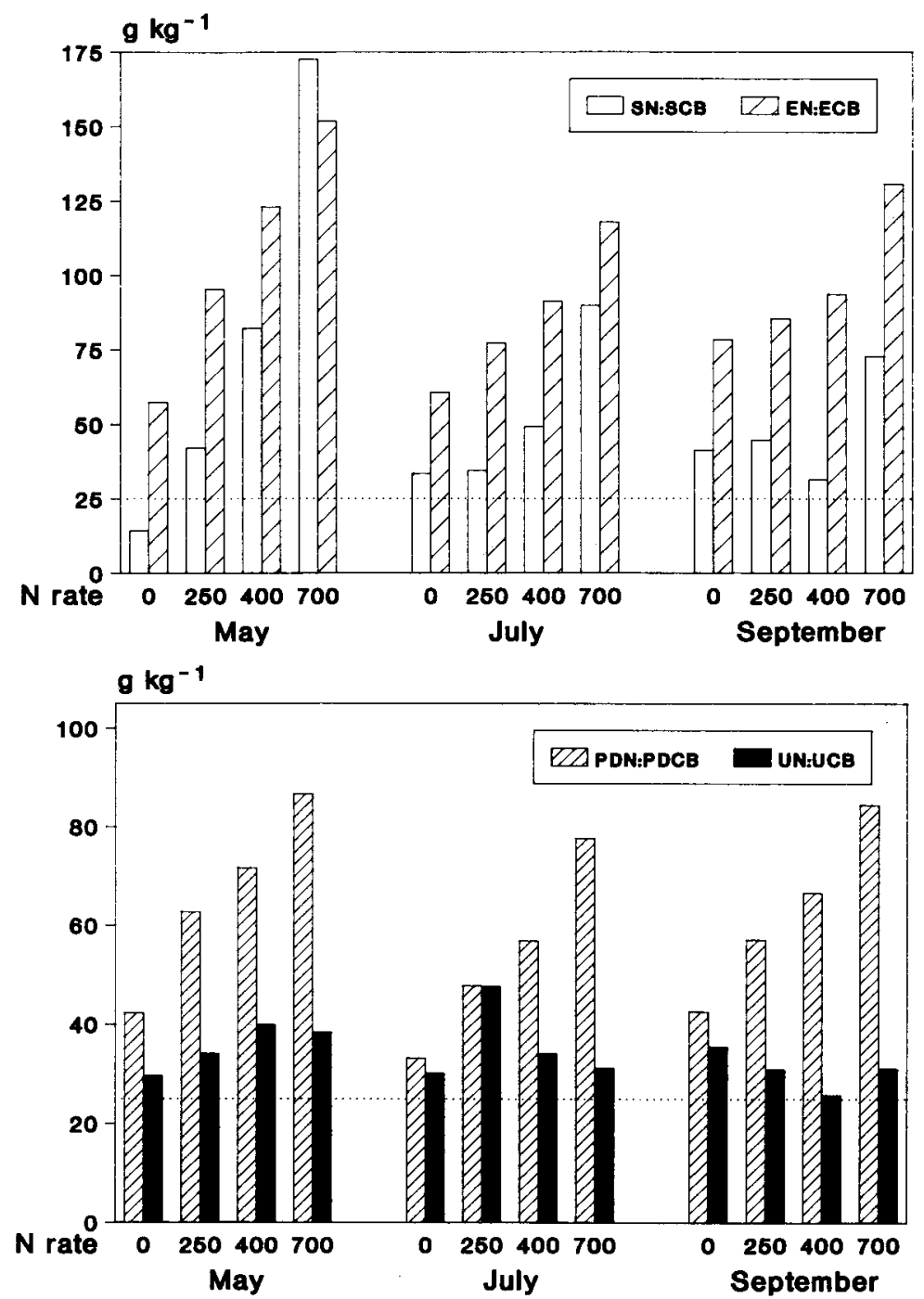

Fig. 2. Effect of rate of nitrogen fertilization $\left(0,250,400\right.$ and $700 \mathrm{~kg} \mathrm{ha}^{-1} \mathrm{yr}^{-1}$, respectively) and season on ratios between nitrogen $(\mathrm{N})$ and carbohydrates $(\mathrm{CB})$ in fresh herbage (Lolium perenne). Experiment 1. $(U=$ undegraded; $P D=$ potentially degradable but escaping from rumen fermentation; $\mathrm{E}=$ potentially degradable effectively fermented in the rumen; $\mathrm{S}=$ soluble).

\section{Effect of maturity (Experiment 2)}

With maturation the $\mathrm{N}$ content decreased from 47.7 to $31.8 \mathrm{~g} \mathrm{~N} \mathrm{~kg}^{-1} \mathrm{DM}$, mainly due to a decrease of FN (van Vuuren, unpublished). The CB content increased with aging (Figure 3). The UCB and PDCB contents decreased between weeks 1 and 3, 


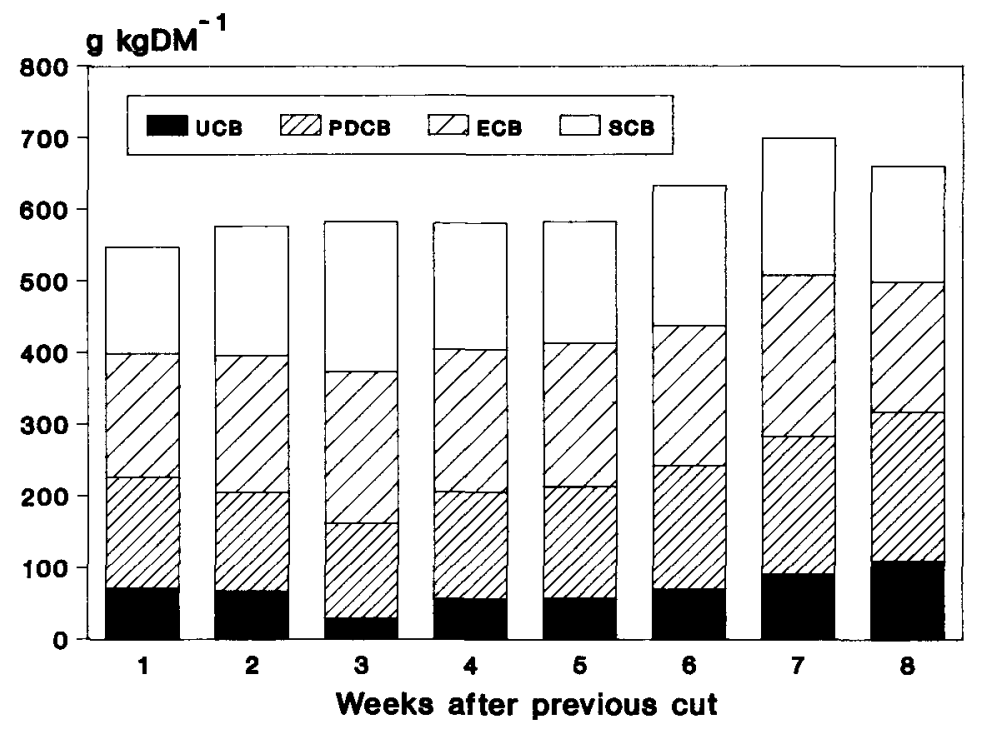

Fig. 3. Effect of maturity (weeks after previous cut) on carbohydrates (CB) in fresh herbage (Lolium perenne). Exp. 2. (UCB = undegradable $\mathrm{CB} ; \mathrm{PDCB}=$ potentially degradable $\mathrm{CB}$ escaping from rumen fermentation; $\mathrm{ECB}=$ potentially degradable $\mathrm{CB}$ effectively fermented in the rumen; $\mathrm{SCB}=$ soluble $\mathrm{CB}$ ).

but from then onwards increased with maturation.

As in Experiment 1 the SN:SCB ratio was lower than the EN:ECB ratio, except in week 1 (Figure 4). After week 2 the EN:ECB ratio decreased with aging. The ratios of SN:SCB and EN:ECB were always higher than $25 \mathrm{~g} \mathrm{~kg}^{-1}$. The ratio of PDN:PDCB increased from week 1 to 3 and subsequently decreased. The UN:UCB ratio was approximately $25 \mathrm{~g} \mathrm{~kg}^{-1}$ and not influenced by aging.

\section{Effect of method of preservation (Experiment 3)}

The SCB of the silages was lower than in the original herbage. The effects of maturation were similar to those found in Experiment 2: with aging $\mathrm{SN}$ and $\mathrm{SCB}$ decreased, while UN, PDCB and UCB increased (Table 1). The SN:SCB and EN:ECB ratios tended to decrease with aging. The EN:ECB ratio was not affected by method of preservation.

Ensiling of grass increased SN especially when ensiled at low DM contents and at the young stages (Tamminga et al., 1990a). Comparing data from Table 1 with those of Figure 3 it may be concluded that ensiling grass decreased the content of SCB except when ensiled without wilting $\left(220 \mathrm{~g} \mathrm{DM} \mathrm{kg}^{-1}\right)$. However, the effect of method of preservation on the SN:SCB ratio was not significant.

Contrary to fresh herbage the SN:SCB ratio in the silages exceeded the EN:ECB ratio. Also in hay $(87.5 \% \mathrm{DM})$ the $\mathrm{SN}$ : $\mathrm{SCB}$ ratio was higher than the EN:ECB ratio. In silages the EN:ECB ratio was slightly above $25 \mathrm{~g} \mathrm{~kg}^{-1}$. The PDN:PDCB ratio ranged between 13 and $27 \mathrm{~g} \mathrm{~kg}^{-1}$; in hay this ratio was higher. 

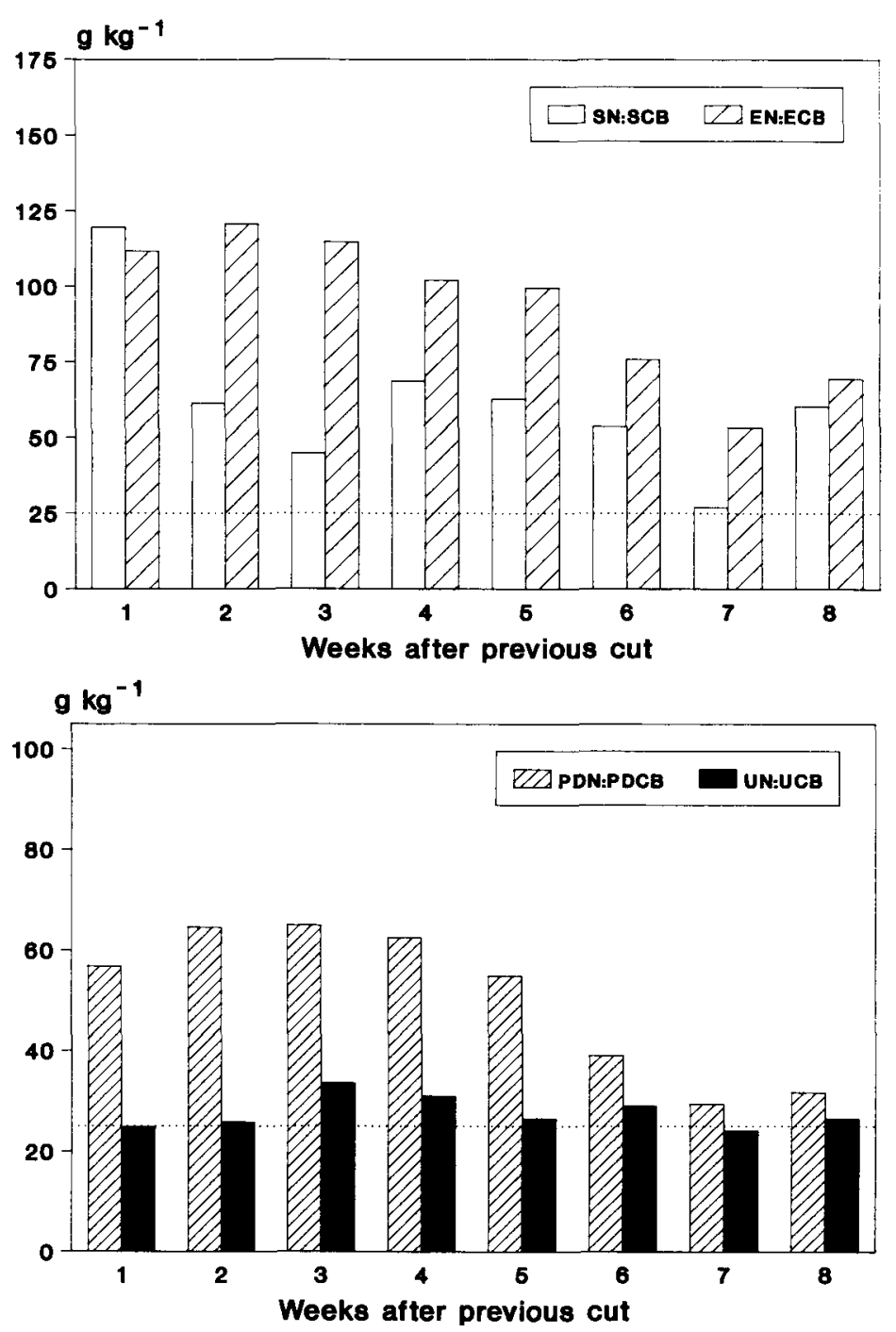

Fig. 4. Effect of maturity (weeks after previous cut) on ratios between nitrogen $(\mathrm{N})$ and carbohydrates (CB) in fresh herbage (Lolium perenne). Experiment 2 . ( $\mathrm{U}=$ undegraded; $\mathrm{PD}=$ potentially degradable but escaping from rumen fermentation; $\mathrm{E}=$ potentially degradable effectively fermented in the rumen; $\mathrm{S}=$ soluble).

\section{Effect of cell wall degrading enzymes (Experiment 4)}

As observed in Experiment 3, maturation increased the CB content of the silages, mainly due to an increase of the undegraded fractions (Figure 5). Generally, treatment with cell wall degrading enzymes increased SCB (Figure 5), as stated earlier (van Vuuren et al., 1989). Also in these silages the SN:SCB ratio exceeded the 
Table 1. Effect of maturity and method of preservation on the rumen availability of nitrogen and carbohydrates of grass silage (Experiment 3).

\begin{tabular}{|c|c|c|c|c|c|c|c|c|c|}
\hline \multirow[t]{2}{*}{ Parameter } & \multicolumn{4}{|c|}{ Maturity (weeks) } & \multicolumn{4}{|c|}{ Preservation (g DM kg-1) } & \multirow{2}{*}{$\begin{array}{l}\text { LSD } \\
P<0.05\end{array}$} \\
\hline & 2 & 4 & 6 & 8 & 220 & 300 & 450 & 875 & \\
\hline $\mathrm{SN}^{1}\left(\mathrm{~g} \mathrm{~kg}^{-1} \mathrm{DM}\right)$ & $29.2^{\mathrm{a} 2}$ & $29.4^{a}$ & $20.6^{b}$ & $14.3^{b}$ & $28.1^{x}$ & $26.4^{x}$ & $24.8^{x}$ & $14.3 y$ & 3.80 \\
\hline $\mathrm{EN}(\mathrm{g} \mathrm{kg} / \mathrm{DM})$ & $10.1^{\mathrm{a}}$ & $8.1^{\mathrm{b}}$ & $6.6^{\mathrm{bc}}$ & $6.3^{c}$ & $5.7 x y$ & $5.2^{x}$ & $6.8 \mathrm{y}$ & $13.4 z$ & 1.49 \\
\hline PDN (g kg-1 DM) & 6.4 & 7.1 & 6.0 & 6.4 & $3.5^{x}$ & $4.2^{x}$ & $6.4 y$ & $11.6^{7}$ & 1.17 \\
\hline $\mathrm{UN}\left(\mathrm{g} \mathrm{kg}{ }^{\prime} \mathrm{DM}\right)$ & $1.9 \mathrm{a}$ & $2.2^{\mathrm{a}}$ & $2.3^{\mathrm{a}}$ & $3.4 \mathrm{~b}$ & $1.4^{x}$ & $2.8 \mathrm{yz}$ & $3.3^{z}$ & $2.4^{y}$ & 0.55 \\
\hline $\mathrm{SCB}\left(\mathrm{g} \mathrm{kg}^{-1} \mathrm{DM}\right)$ & 124 & 117 & 109 & 105 & $163^{x}$ & $107 y$ & $100 y$ & $86^{y}$ & 42.0 \\
\hline $\mathrm{ECB}\left(\mathrm{g} \mathrm{kg}^{-1} \mathrm{DM}\right)$ & $168^{\mathrm{a}}$ & $168^{\mathrm{a}}$ & $192 \mathrm{~b}$ & $186^{b}$ & $184 x$ & $171 x y$ & $165 y$ & $194^{x}$ & 13.8 \\
\hline PDCB $\left(\mathrm{g} \mathrm{kg}^{-1}\right.$ DM) & $191^{\mathrm{a}}$ & $210^{\mathrm{a}}$ & $244 b$ & $259 \mathrm{~b}$ & $192^{x}$ & $226^{x y}$ & $237 y$ & $250 \mathrm{y}$ & 36.5 \\
\hline UCB $\left(\mathrm{g} \mathrm{kg}^{-1} \mathrm{DM}\right)$ & $67 \mathrm{a}$ & $60^{a}$ & $80^{\mathrm{b}}$ & $115^{\mathrm{c}}$ & $56^{x}$ & $96 y$ & $89 y$ & $80 y$ & 18.3 \\
\hline $\mathrm{SN}: \mathrm{SCB}\left(\mathrm{g} \mathrm{kg}^{-1} \mathrm{CB}\right)$ & 235 & 265 & 196 & 144 & 171 & 247 & 251 & 172 & 121.5 \\
\hline EN:ECB (g kg-1 CB) & $57^{a}$ & $46^{b}$ & $36^{c}$ & $34 c$ & $32 x$ & $30 \mathrm{x}$ & $39 x$ & $73 y$ & 9.6 \\
\hline PDN:PDCB $\left(\mathrm{g} \mathrm{kg}^{-1} \mathrm{CB}\right)$ & $33^{a}$ & $32^{a b}$ & $24 b$ & $25^{b}$ & $19^{x}$ & $20^{x}$ & $27 x$ & $49 y$ & 8.0 \\
\hline UN:UCB ( $\left.\mathrm{g} \mathrm{kg}^{-1} \mathrm{CB}\right)$ & $27^{a}$ & $34^{b}$ & $28^{\mathrm{a}}$ & $29 a$ & $26^{x}$ & $29 x z$ & $34 y z$ & $30^{z}$ & 3.9 \\
\hline
\end{tabular}

$1 \mathrm{SN}=$ soluble $\mathrm{N} ; \mathrm{EN}=$ insoluble effectively degraded $\mathrm{N} ; \mathrm{PDN}=$ degradable $\mathrm{N}$ escaping from rumen fermentation; $\mathrm{UN}=$ undegradable $\mathrm{N} ; \mathrm{SCB}=$ soluble non-protein organic matter; $\mathrm{ECB}=$ insoluble effectively degradable non-protein organic matter; $\mathrm{PDCB}=$ degradable non-protein organic matter escaping from rumen fermentation; $\mathrm{UCB}=$ undegradable non-protein organic matter.

2 Figures with different superscript differ significantly $(P<0.05)$.

EN:ECB ratio (Figure 6). The SN:SCB ratio in enzyme-treated silages was usually lower than in the untreated silages.

\section{Discussion}

In this study, we have distinguished ruminal available $\mathrm{CP}$ and $\mathrm{CB}$ into a soluble fraction (S), assumed to be instantly and completely available in the rumen, and an insoluble, effectively degraded fraction (E). Our approach resulted in static figures and we realize that a more kinetic model is needed to describe the nutrient flow in ruminants more accurately. For such an approach nylon bag residues should be fitted using a model in which rate of degradation is not a constant. This method requires more data of short term incubations than we obtained in our studies.

\section{Fresh herbage}

In dairy cows fed young highly fertilized herbage, the duodenal protein supply may be relatively low and only meet the requirements of maintenance and a production of approximately $25 \mathrm{~kg}$ milk per day (Beever \& Siddons, 1985). This is mainly caused by an extensive $\mathrm{CP}$ degradation in the rumen, while the intake of energy is too low to compensate for this loss by the synthesis of microbial protein. Besides, a large proportion of the energy available for microbial growth has to come from 


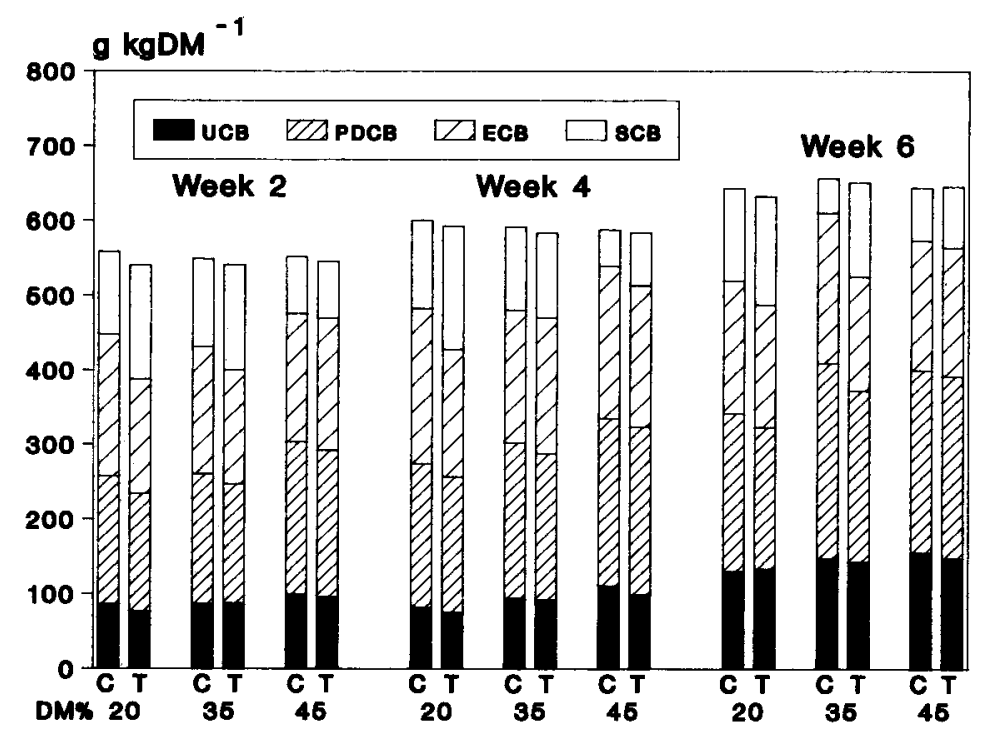

Fig. 5. Effect of maturity (weeks after previous cut), DM content $(20,30$ and $45 \%$ ) and cell wall degrading enzymes $(C=$ control; $T=$ treated $)$ on carbohydrates $(\mathrm{CB})$ in grass silage. Experiment 4. ( $\mathrm{UCB}=$ undegradable $\mathrm{CB}$; $\mathrm{PDCB}=$ potentially degradable $\mathrm{CB}$ escaping from rumen fermentation; $\mathrm{ECB}=$ potentially degradable $\mathrm{CB}$ effectively fermented in the rumen; $\mathrm{SCB}=$ soluble $\mathrm{CB}$ ).

protein and soluble sugars, which will yield less ATP per kg fermented OM than cell wall carbohydrates (Demeyer \& Tamminga, 1987). An important consequence of this situation is an excessive loss of urea $\mathrm{N}$ via the urine (van Vuuren \& Meijs, 1987).

Synchronization of the availability of $\mathrm{N}$ and $\mathrm{CB}$ in the rumen is considered to be an important condition for optimizing microbial protein synthesis. This can be achieved by optimizing both the SN:SCB and EN:ECB ratios. Usually the SN:SCB ratio of fresh herbage exceeds $25 \mathrm{~g} \mathrm{~kg}^{-1}$, the value considered as an optimum for microbial protein synthesis (Czerkawski, 1986). In one occasion (Figure 2) the $\mathrm{SN}: \mathrm{SCB}$ in fresh grass was lower than this value. A temporary deficit of SN can however be compensated for by SN from urea constantly secreted to the rumen in saliva and via diffusion through the rumen wall (Cheng \& Costerton, 1980). Increasing the SN content in fresh grass by higher $\mathrm{N}$ fertilization seems therefore less appropiate. High SN:SCB ratios were observed in young herbage intensively fertilized, where a high proportion of $\mathrm{N}$ may be present in the form of non-protein nitrogen, presumably nitrate (Mangan, 1982).

The EN:ECB ratio in fresh herbage usually exceeds the SN:SCB ratio and the desired value of $25 \mathrm{~g} \mathrm{~kg}^{-1}$. To prevent excessive $\mathrm{N}$ losses from the rumen a decrease of the EN:ECB ratio seems more appropiate. Theoretically a lower EN:ECB ratio in the diet can be achieved either by decreasing the ratio in the herbage by varying growing conditions or by changing the EN:ECB ratio in the diet by supplementing with appropriate concentrate ingredients. Desired growing conditions leading to an optimal $\mathrm{EN}$ :ECB ratio were deduced from the data of Experi- 

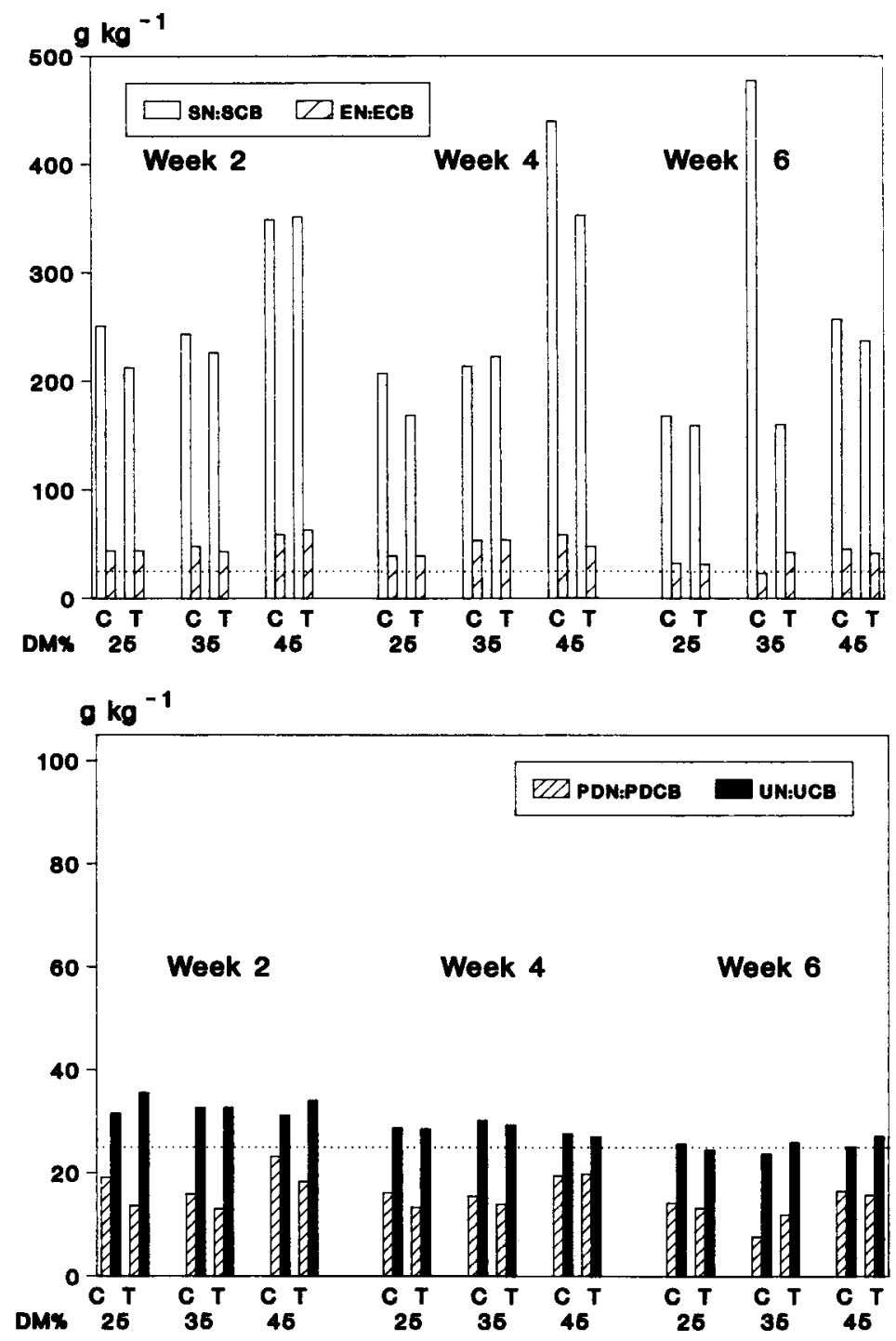

Fig. 6. Effect of maturity (weeks after previous cut), DM content $(20,30$ and $45 \%)$ and cell wall degrading enzymes $(C=$ control; $T=$ treated $)$ on ratios between nitrogen $(N)$ and carbohydrates $(C B)$ in grass silage. Experiment 4. $(\mathrm{U}=$ undegraded; $\mathrm{PD}=$ potentially degradable but escaping from rumen fermentation; $\mathrm{E}=$ potentially degradable effectively fermented in the rumen; $\mathrm{S}=$ soluble).

ments 1 and 2. Predictions of EN:ECB in fresh herbage by multiple regression analysis were only significant with $\mathrm{N}$ content and time between April 1 and day of cutting (Table 2). The equations to predict EN:ECB obtained in Experiment 1 were similar to those of Experiment 2. From these equations it may be concluded that an optimum EN:ECB ratio will be reached at a $\mathrm{N}$ content of 11 (Experiment 1) to 
Table 2. Parameters in multiple regression equations for the prediction of rumen-available nutrients of grass $(P<0.05)$.

\begin{tabular}{|c|c|c|c|c|c|}
\hline $\mathrm{Y}$ & Experiment & Constant & $\mathrm{X}_{1^{\mathrm{a}}}$ & $\mathrm{X}_{2}^{\mathrm{b}}$ & $\mathrm{R}^{2}$ \\
\hline $\mathrm{SN}: \mathrm{SCB}$ & $\begin{array}{l}1 \\
2\end{array}$ & $\begin{array}{r}-126.8 \\
-29.9\end{array}$ & $\begin{array}{l}4.27 \\
2.37\end{array}$ & & $\begin{array}{l}0.515 \\
0.391\end{array}$ \\
\hline EN:ECB & 1 & $\begin{array}{r}-6.3 \\
-22.3 \\
-24.2\end{array}$ & $\begin{array}{l}2.74 \\
2.86 \\
3.03\end{array}$ & 0.10 & $\begin{array}{l}0.878 \\
0.911 \\
0.922\end{array}$ \\
\hline FN:FCB & $\begin{array}{l}1 \\
2\end{array}$ & $\begin{array}{l}-43.5 \\
-25.8\end{array}$ & $\begin{array}{l}3.20 \\
2.68\end{array}$ & & $\begin{array}{l}0.948 \\
0.882\end{array}$ \\
\hline
\end{tabular}

a $\mathrm{X}_{1}=\mathrm{N}$ content $\left(\mathrm{g} \mathrm{kg}^{-1} \mathrm{DM}\right)$

b $\mathrm{X}_{2}=$ days between April 1 and cutting date

c $\mathrm{SN}=$ soluble $\mathrm{N} ; \mathrm{SCB}=$ soluble non-protein organic matter; $\mathrm{EN}=$ insoluble effectively degraded $\mathrm{N}$; $\mathrm{ECB}=$ insoluble effectively degraded non-protein organic matter; $\mathrm{FN}=$ fermented $\mathrm{N} ; \mathrm{FCB}=$ fermented non-protein organic matter.

16 (Experiment 2) $\mathrm{g} \mathrm{kg}^{-1} \mathrm{DM}$. Such low $\mathrm{N}$ contents require low rates of $\mathrm{N}$ fertilization $\left(<200 \mathrm{~kg} \mathrm{ha}^{-1} \mathrm{yr}^{-1}\right)$ at which the annual DM yield ha-1 will be substantially lower (Prins, 1983).

As the EN:ECB ratio in fresh herbage always exceeded $25 \mathrm{~g} \mathrm{~N} \mathrm{~kg}^{-1} \mathrm{DM}$ and an adequate decrease of this ratio may have negative consequences for herbage yield, one may conclude that grazing dairy cows should preferable be supplemented with rumen degradable carbohydrates. The rate of $\mathrm{CP}$ degradation of fresh herbage is relatively high: 0.08 to $0.14 \mathrm{~h}^{-1}$ (van Vuuren, unpublished). Thus for optimum synchronization the supplement should have a rate of $\mathrm{CB}$ degradation similar to that of herbage CP. Concentrate ingredients characterized by a low EN:ECB ratio and a high rate of $\mathrm{CB}$ degradation are beet pulp, rice and tapioca (Tamminga et al., 1990b). Corn, milo and potato are also low in EN:ECB, but their rate of degradation is lower: around $0.05 \mathrm{~h}^{-1}$ (Tamminga et al., 1990b). Van Vuuren \& Meijs (1987) and Valk (1990) reported a higher milk protein production by cows, when 35 to $50 \%$ of grass DM was substituted by maize silage or by concentrates based on corn or beet pulp. This observation may indicate an improvement of the nutrient supply.

\section{Silage}

In animals given silage-based diets the efficiency of microbial protein synthesis ( $\mathrm{g}$ microbial protein $\mathrm{kg}^{-1} \mathrm{OM}$ fermented in the rumen) is usually low. This is attributed to the fact that a variable portion of OM consists of silage fermentation products, which will not contribute to the energy supply of rumen micro-organisms (Thomas, 1982). Our data suggest that asynchronous $N$ and $C B$ availabilities may also contribute to the low efficiency.

Different from fresh herbage, preserved herbage (silage or hay) was characterized by a high SN:SCB ratio, exceeding the EN:ECB ratio. The high $\mathrm{N}$ solubility of 
silages results primarily from the extensive proteolysis of herbage protein during wilting and ensiling (McDonald, 1982). The high SN:SCB ratio may be a reason for the ineffective microbial protein synthesis on silage-based diets, the more since part of SCB may be fermentation products, which do not contribute to the energy supply of the micro-organisms.

The high SN:SCB ratio, in which SCB contains a certain portion of fermentation products, would suggest positive effects of feeding easily available carbohydrates when feeding grass silage. Products high in SCB and with a low SN:SCB ratio are barley, tapioca, oats, wheat and wheat flour (Tamminga et al., 1990b). To achieve full potential of such a strategy the silage and supplements should be consumed regularly over the day (complete mixture or computerized feed supply). Starch of barley, oats, tapioca, wheat and wheat flour is rapidly degradable (Tamminga et al., 1990b) which may lead to unfavourable conditions in the rumen, when consumed in a short time at large amounts (Malenstein et al., 1984). Thus also in this respect a regular consumption over the day is preferable, while the level of intake of these ingredients should be restricted.

Syrjala (1972) and Chamberlain et al. (1985) reported a reduction of the ruminal $\mathrm{NH}_{3}-\mathrm{N}$ concentration when supplementing silage diets with sucrose and glucose. However, Chamberlain et al. (1985) indicated that starchy ingredients may stimulate the number of protozoa, thereby diminishing the positive effect of extra CB on the efficiency of microbial protein synthesis.

The EN:ECB ratio in silages with a low DM content may be relatively low (Table 1; Figure 5). Thus when feeding such type of silage the $N$ availability may be too low for optimal protein synthesis in long feeding intervals. Indeed, Rooke et al. (1987) observed low ruminal $\mathrm{NH}_{3}-\mathrm{N}$ levels $\left(<3\right.$ mmol $\left.1^{-1}\right) 6$ hours after feeding moderately wilted silage (229 $\left.\mathrm{g} \mathrm{DM} \mathrm{kg}^{-1} ; 18.4 \mathrm{~g} \mathrm{~N} \mathrm{~kg}^{-1} \mathrm{DM}\right)$ to dairy cows. In their experiments, continuous intraruminal infusions of urea or casein, expected to increase $\mathrm{N}$ supply to the rumen biota, had no effect on microbial protein synthesis.

\section{Acknowledgements}

The assistance of J. J. van der Tol, P. Pijper, T. van Iersel (Wageningen Agricultural University) and K. Bergsma (Agricultural College, Dronten), who performed part of the nylon bag incubations, is highly appreciated.

\section{References}

Beever, D. E. \& R. C. Siddons, 1986. Digestion and metabolism in the grazing ruminant. In: L. P. Milligan, W. L. Grovum \& A. Dobson (Eds), Control of digestion and metabolism in ruminants, p. 479497. Prentice-Hall, Englewood Cliffs, NJ.

Chamberlain, D. G., P. C. Thomas, W. Wilson, C. J. Newbold \& J. C. MacDonald, 1985. The effects of carbohydrate supplements on ruminal concentrations of ammonia in animals given diets of grass silage. Journal of Agricultural Science (Cambridge) 104: 331-340.

Cheng, K.-J. \& J. W. Costerton, 1980. Adherent rumen bacteria - their role in the digestion of plant material, urea and epithelial cells. In: Y. Ruckebusch \& P. Thivend (Eds), Digestive physiology and metabolism in ruminants, p. 227-250. MTP Press, Lancaster. 


\section{A.M. VAN VUUREN, S. TAMMINGA AND R.S. KETELAAR}

Czerkawski, J. W., 1986. An introduction to rumen studies. Pergamon Press, Oxford, $236 \mathrm{pp}$.

Demeyer, D. I. \& S. Tamminga, 1987. Microbial protein yield and its prediction. In: R. Jarrige \& G. Alderman (Eds), Feed evaluation and protein requirement systems for ruminants, EUR 10657 EN, p. 129-144. Commission of the European Communities, Luxembourg.

Gill, M., D. E. Beever \& D. F. Osbourn, 1989. The feeding value of grass and grass products. In: W. Holmes (Ed.), Grass: Its production and utilization, p. 89-129. Blackwell Scientific Publications, Oxford.

Henderson, A. R., P. McDonald \& D. Anderson, 1982. The effect of cellulase preparation derived from Trichoderma viride on the chemical changes during the ensilage of grass, lucerne and clover. Journal of the Science of Food and Agriculture 33: 16-20.

Mangan, J. L., 1982. The nitrogenous constituents of fresh forages. In: D. J. Thomson, D. E. Beever \& R.G. Gunn (Eds), Forage protein in ruminant animal production, p. 25-40. Occasional Publication No. 6, British Society of Animal Production.

McDonald, P., 1982. The effect of conservation processes on the nitrogenous components of forages. In: D. J. Thomson, D. E. Beever \& R. G. Gunn (Eds), Forage protein in ruminant animal production, p. 41-49. Occasional Publication No. 6, British Society of Animal Production.

Mehrez, A. Z. \& E. R. Orskov, 1977. A study of the artificial fibre bag technique for determining the digestibility of feeds in the rumen. Journal of Agricultural Science (Cambridge) 88: 645-650.

Payne, R. W., P. W. Lane, A. E. Ainsley, K. E. Bicknell, P. G. N. Digby, S. A. Harding, P. K. Leech, H. R. Simpson, A. D. Todd, P. J. Verrier \& P. W. White, 1987. Genstat 5 Reference Manual. Clarendon Press, Oxford, $749 \mathrm{pp}$.

Prins, W. H., 1983. Limits to nitrogen fertilizer on grassland. Doctoral thesis, Wageningen Agricultural University, $132 \mathrm{pp}$.

Robinson, P. H., J. G. Fadel \& S. Tamminga, 1986. Evaluation of mathematical models to describe neutral detergent residue in terms of its susceptibility to degradation in the rumen. Animal Feed Science and Technology 15: 249-271.

Rooke, J. A., N. H. Lee \& D. G. Armstrong, 1987. The effects of intraruminal infusions of urea, casein, glucose syrup and a mixture of casein and glucose syrup on nitrogen digestion in the rumen of cattle receiving grass-silage diets. British Journal of Nutrition 57: 89-98.

Syrjala, L., 1972. Effect of different sucrose, starch and cellulose supplements on the utilization of grass silages by ruminants. Agriculturae Fenniae 11: 199-276.

Tamminga, S., 1986. Utilization of naturally occuring NPN-compounds by ruminants. Archives of Animal Nutrition 36: 169-176.

Tamminga, S., R. Ketelaar \& A. M. van Vuuren, 1990a. Degradation of N in conserved forages in the rumen of dairy cows. Grass and Forage Science (in press).

Tamminga, S., A. M. van Vuuren, C. J. van der Koelen, R. S. Ketelaar \& P. L. van der Togt, 1990b. Ruminal behaviour of structural carbohydrates, non-structural carbohydrates and crude protein from concentrate ingredients in dairy cows. Netherlands Journal of Agricultural Science 38: 513-526.

Thomas, P. C., 1982. Utilization of conserved forages. In: D. J. Thomson, D. E. Beever \& R. G. Gunn (Eds), Forage protein in ruminant animal production, p. 67-76. Occasional Publication No. 6, British Society of Animal Production.

Valk, H., H. W. Klein Poelhuis \& H. J. Wentink, 1990. The effect of fibrous and starchy carbohydrates in concentrate-mixtures as supplements in a herbage-based diet for high-yielding dairy cows. Netherlands Journal of Agricultural Science 38: 475-486.

Vuuren, A. M. van, K. Bergsma, F. Krol-Kramer \& J. A. C. van Beers, 1989. Effects of addition of cell wall degrading enzymes on the chemical composition and the in sacco degradation of grass silage. Grass and Forage Science 44: 223-230.

Vuuren, A. M. van, C. J. van der Koelen \& J. Vroons-de Bruin, 1986. Influence of level and composition of concentrate supplements on rumen fermentation patterns of grazing dairy cows. Netherlands Journal of Agricultural Science 34: 457-467.

Vuuren, A. M. van \& J. A. C. Meijs, 1987. Effects of herbage composition and supplement feeding on the excretion of nitrogen in dung and urine by grazing dairy cows. In: H. G. van der Meer, R. J. Unwin, T. A. van Dijk \& G. C. Ennik (Eds), Animal manure on grassland and fodder crops: Fertilizer or waste? p. 17-25. Martinus Nijhoff, Dordrecht, Netherlands. 